\title{
The possible value of ascorbic acid as a prophylactic agent for urinary tract infection
}

\author{
T Castelló, L Girona, MR Gómez, A Mena Mur and L García \\ Pharmacy Department, Spinal Cord Injury Unit, Service of Rehabilitation, Hospital de Traumatologia i Rehabilitació \\ Vall d'Hebron, Barcelona, Spain
}

The effect of ascorbic acid on urine $\mathrm{pH}$ was studied in spinal cord injury patients. Their urine was not colonized by urease positive microorganisms. The study was designed to compare the baseline urine $\mathrm{pH}$ value and the urine $\mathrm{pH}$ value after the administration of placebo or ascorbic acid $500 \mathrm{mg} / 6 \mathrm{~h}$. The diet and medical treatment were not controlled. A significant decrease in urine $\mathrm{pH}$ value was not obtained. There was no clinical benefit from the use of ascorbic acid.

Keywords: ascorbic acid; urinary acidifying agent; urinary tract infection; spinal cord injured patients

\section{Introduction}

Many patients with a spinal cord injury have a neuropathic bladder and the urine is often colonized by bacteria. Sometimes such patients can synthetize a urease enzyme which helps to alkalinize the urine by the conversion of urea into ammonia. ${ }^{1}$

In the urine there are hipuric-acid and betahidroxibutiric acid, which are bacteriostatic and need a low $\mathrm{pH}$ to attack the bacteria wall with an antibacterial action. ${ }^{1}$

To reduce the frequency of urinary infection in such patients, acidification has been used as a prophylactic to inhibit bacterial growth.

In our department we have used ascorbic acid in a dose of $2 \mathrm{~g}$ four times a day, as a previous study demonstrated the value of acidifying the urine, controlling the diet and providing pharmacological treatment. $^{3}$ In the literature there is a controversy about the acidifying capacity of ascorbic acid. ${ }^{4}{ }^{8}$ Also in high doses there may be the appearance of oxalate crystals. $^{2,9}$

\section{Objective}

The aim of this study was to measure the clinical effectiveness of ascorbic acid as a prophylactic agent for urinary tract infection.

\section{Materials and methods}

The study involved patients with a traumatic spinal cord injury, treated in our Spinal Cord Injury Unit. All agreed to participate in the study.
A randomized, simple-blind study was made with ascorbic acid, and as the placebo, lactose. There was no control over the diet, nor of drugs with an alkalizing effect that could modify the urine $\mathrm{pH}$.

Initially, for a week, patients did not receive any acidifier, then patients were randomized in two groups: (1) giving ascorbic acid $2 \mathrm{~g}$ day (one tablet of $500 \mathrm{mg}$ four times a day).

(2) giving placebo of lactose (one capsule four times a day).

At the beginning, no patient had clinical signs of infection that could modify the results. They had a neuropathic bladder and used intermittent catheterization or had an indwelling catheter. The established definitions of the Center for Diseases Control (CDC), Atlanta USA were used for the diagnosis of a urinary tract infection. ${ }^{10}$

Estimation of the urine $\mathrm{pH}$, and uroculture were carried out to identify any microorganisms and to see if they were urease positive.

Clinical symptoms of urinary infection were analyzed by the same physician to ensure homogenicity.

Statistical analysis of the results was made by applying Fisher's exact test for proportion comparison, and the $t$ Student Fisher's test for mean comparison.

\section{Results}

Thirty-eight patients began the study, which started in February 1990, and finished in July 1991. Twenty-five patients were omitted for different reasons.

Thirteen patients completed the study. The distribution between the two groups (ascorbic acid-placebo) was well balanced. No statistical differences were observed (Table 1). 
Table 1 Description of the 13 patients who completed the study

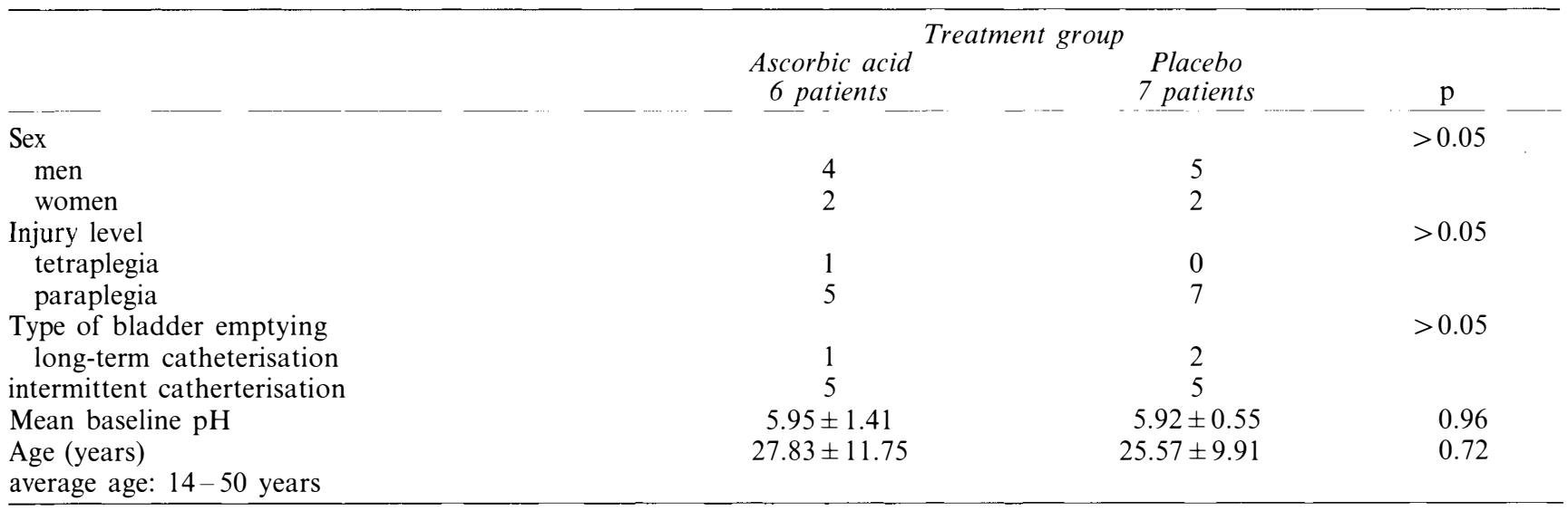

Table 2 Urine $\mathrm{pH}$ values

\begin{tabular}{|c|c|c|c|c|}
\hline $\begin{array}{l}\text { Patient } \\
\text { number }\end{array}$ & Treatment & $\begin{array}{l}\text { Mean } \\
\text { baseline } \\
\text { pH }\end{array}$ & $\begin{array}{c}\text { Mean } \\
p H \\
\text { Ascorbic ac. }\end{array}$ & $\begin{array}{c}\text { Mean pH } \\
(*) \\
\text { difference }\end{array}$ \\
\hline 1 & placebo & 5.26 & 5.07 & -0.19 \\
\hline 2 & ascorbic acid & 5.46 & 5.92 & +0.46 \\
\hline 3 & ascorbic acid & 5.40 & 5.17 & -0.23 \\
\hline 4 & ascorbic acid & 5.48 & 5.16 & -0.32 \\
\hline 5 & placebo & 5.96 & 6.57 & +0.61 \\
\hline 6 & placebo & 5.95 & 5.24 & -0.71 \\
\hline 7 & ascorbic acid & 5.71 & 6.18 & +0.47 \\
\hline 8 & placebo & 5.56 & 5.57 & +0.01 \\
\hline 9 & placebo & 5.52 & 5.00 & -0.52 \\
\hline 10 & ascorbic acid & 8.76 & 7.59 & -1.17 \\
\hline 11 & placebo & 6.31 & 5.72 & -0.59 \\
\hline 12 & placebo & 6.87 & 5.78 & -1.09 \\
\hline 13 & ascorbic acid & 4.86 & 5.07 & +0.21 \\
\hline
\end{tabular}

Mean and standard deviation for ascorbic acid groups: $-0.10 \pm 0.62$. Mean and standard deviation for placebo group: $-0.35 \pm 0.55 .\left(^{*}\right)$ Sign -: $\mathrm{pH}$ decrease with the administration of ascorbic acid in relation to the control week. Sign $+: \mathrm{pH}$ increase with the administration of ascorbic acid in relation to the control week

The differences between the mean $\mathrm{pH}$ values for the two groups were obtained with the mean urine $\mathrm{pH}$ values during the first control week (mean baseline $\mathrm{pH}$ ) and the mean urine $\mathrm{pH}$ after administration of ascorbic acid or placebo (Table 2). Statistical analysis of these differences failed to demonstrate any significant difference.

Patients developed their urinary infection between the sixth and eighth day after beginning the administration of ascorbic acid or placebo. Two belonged to the ascorbic acid group and one to the placebo group. A statistical difference was not observed between the two groups.

\section{Discussion}

In this study, a decrease in the urine $\mathrm{pH}$ and the possible prophylactic effect of ascorbic acid were not obtained when there was no control over the diet nor of alcalizing drugs.

We consider that many external variables can modify the urine $\mathrm{pH}$ value, especially diet and pharmacological treatment.

\section{Conclusion}

The administration of ascorbic acid is not effective as a urinary acidifier in conditions without controlling the diet and pharmacological treatment. Also, it is not a useful drug to prevent urinary tract infection.

\section{References}

1 Sobel JD, Kaye D. Urinary tract infection. In: Mandell GL, Douglas RG, Bennett JE, ed. Principles and Practice of Infectious Diseases. 3rd ed. John Whiley \& Sons, Inc., 1990.

2 Drug Information for the Health Care Provider. USP DI. Seventh Edition 1987. The United States Pharmacopeial Convection, Inc.

3 Girona L, et al. Efectividad del ácido ascórbico como acidificante urinario en pacientes con vejiga neurógena por lesión medular. Urod A 1990; 2: 91 - 94.

4 Hetey SK, et al. Effect of ascorbic acid on urine $\mathrm{pH}$ in patients with injured spinal cords. Am J Hosp Pharm 1980; 37: 235-237.

5 Murphy FJ, Zelman S, Mau W. Ascorbic acid as a urinary acidifying agent: 2. Its adjunctive role in chronic urinary infection. $J$ Urol 1965; 94: 300-303.

6 Nahata MC, Shimp L, Lampman T, McLeod DC. Effect of ascorbic acid on urine pH in man. Am J Hosp Pharm 1977; 34: $1234-1237$

7 Muiznieks VE. Effect of oral vitamin C on urine pH. Can J Hosp Pharm 1978; 31: $18-22$.

8 Barton $\mathrm{CH}$, et al. Ineffectiveness of intravenous ascorbic acid as an acidifying agent in man. Arch Intern Med 1981; 141: 211-212.

9 Bannwart C, et al. Beeinflussung des Urin-pH durch Ascorbinsäure. Helv Chir Acta 1981; 48: 425-428.

10 Garner JS, et al. CDC definitions for nosocomial infections. Am J Infect Control 1988; 16: $128-140$.

11 Gibaldi M, Grundhofer B, Levy G. Effect of antiacids on $\mathrm{pH}$ urine. Clin Pharmacol Ther 1974; 16: 520-525. 